\title{
PERSEPSI DALAM PEMBELAJARAN PENDEKATAN KETERAMPILAN PROSES TERHADAP KEMAMPUAN KONEKSI MATEMATIS SISWA (STUDI PENELITIAN DI SMP NEGERI 1 WANRAJA)
}

\author{
Rini Pitriani', Ekasatya Aldila Afriansyah ${ }^{2}$ \\ e_satya@yahoo.com \\ Pendidikan Matematika, STKIP Garut \\ 2016
}

\begin{abstract}
Abstrak
Kemampuan koneksi matematis merupakan hal yang penting namun siswa yang menguasai konsep matematika tidak dengan sendirinya pintar dalam mengoneksikan matematika. Koneksi matematis merupakan suatu keterampilan yang harus dibangun dan dipelajari. Kegiatan penyelesaian masalah kontekstual merupakan aktivitas yang membantu siswa untuk dapat mengetahui hubungan berbagai konsep dalam matematika dan mengaplikasikan matematika dalam kehidupan sehari-hari. Pendekatan keterampilan proses pada hakikatnya adalah suatu pengelolaan kegiatan belajar-mengajar yang berfokus pada pelibatan siswa secara aktif dan kreatif dalam proses pemerolehan hasil belajar. Penelitian ini dilakukan dengan tujuan untuk mengetahui pengaruh persepsi siswa tentang pembelajaran pendekatan keterampilan proses terhadap kemampuan koneksi matematis siswa dalam pengajaran matematika pada pokok bahasan Lingkaran. Jenis penelitian yang digunakan adalah eksperimen. Populasi dalam penelitian ini adalah seluruh siswa kelas VIII SMP Negeri 1 Wanaraja dan untuk sampel dipilih satu kelas yang diambil secara acak, yaitu kelas VIII-A. Dalam penelitian ini penulis menggunakan instrumen yang terdiri dari tes kemampuan koneksi berupa tes uraian (tes akhir) yang sebelumnya di uji cobakan kepada siswa kelas 1X-A di SMP Negeri 1 Wanaraja dan angket. Analisis data dilakukan dengan korelasi Rank Sperman dan dilanjutkan dengan uji t,dari perhitungan diperoleh Ho ditolak, artinya Ha diterima sehingga terdapat pengaruh yang positif persepsi siswa tentang pembelajaran pendekatan keterampilan proses (PKP) terhadap kemampuan koneksi matematis siswa. Sedangkan untuk analisis kemampuan koneksi matematis siswa secara keseluruhan berinterpretasi baik dan persepsi siswa terhadap pembelajaran matematika dengan Pendekatan Keterampilan Proses menunjukan interpretasi yang baik pula.
\end{abstract}

Kata kunci: kemampuan koneksi matematis, pendekatan keterampilan proses, persepsi siswa, penelitian eksperimen

\footnotetext{
Abstract

Mathematical connection ability is an important aspect. However, it is not all students who master mathematical concepts, master to create such mathematical connection. Mathematical connection is an ability that should be emerged and learned. A contextual problem solving activity is an activity that can help students to recognize the connection between concepts in mathematics and to utilize mathematics in everyday life. A process skill based approach is an organizing activity around teaching leraning which focuses on student engagement both actively and creatively in a learning outcome acquisition. This study was conducted in order to get information about the effect of students' perception on learning activity by using a process skill approach towards students' ability of
} 
JURNAL GANTANG Pendidikan Matematika FKIP - UMRAH

Vol. 1 No. 2, Desember 2016, p-ISSN. 2503-0671, e-ISSN. 2548-5547

mathematical connection on the topic of circle. The frame of study was an experiment. The population of the study were $8^{\text {th }}$ graders of SMP Negeri 1 Wnaraja. The sample was determined randomly, and it was students of VIII-A. The instrument of the study was test of connection ability in form of essay (posttest) which was tested prior to study to students of IX-A of the same school. The questionnaire was another instrument which was used throughout the study. Data analysis was conducted by using Rank Sperman correlation followed by $t$-test. From the calculation, it was obtained that Ho was rejected, which meant that Ha was accepted simultaneously implying that there was a positive effect on students' perception about learning activity which used a process skill approach towards students' mathematical connection ability. On the other hand, based on the analysis, it was shown that students' mathematical connection ability was generally interpreted 'good' as well as the students' perception on this process skill approeached-learning.

Keywords: mathematical connection ability, process skill approach, students' perception, experimental research

\section{Pendahuluan}

Pendidikan adalah usaha sadar dan terencana untuk mewujudkan suasana belajar dan proses pembelajaran agar peserta didik secara aktif dapat mengembangkan potensi dirinya untuk memiliki kekuatan spiritual keagamaan, pengendalian diri, kepribadian, kecerdasan, akhlak mulia, serta keterampilan yang diperlukan dirinya, masyarakat, bangsa dan Negara (UUSPN No.20 pasal 1 ayat 1). Artinya pendidikan mempunyai peranan yang sangat penting bagi kehidupan manusia. Karena dengan adanya pendidikan, maka manusia akan mempunyai pandangan dan arah hidup yang lebih jelas dan terarah.

Kurikulum Tingkat Satuan Pendidikan (KTSP) 2006 (dalam Cancan 2014:2) menyatakan bahwa "matematika merupakan pengetahuan universal yang mendasari perkembangan teknologi modern, mempunyai peranan penting dalam berbagai disiplin dan pengembangan daya pikir manusia".

Lisnawati (dalam Cancan 2014:3) mengungkapkan bahwa melalui koneksi matematis, wawasan siswa akan semakin terbuka terhadap matematika, yang kemudian akan menimbulkan sikap positif terhadap matematika itu sendiri. Melalui proses koneksi matematis, konsep pemikiran dan wawasan siswa terhadap matematika akan semakin terbuka luas, tidak hanya terfokus pada topik yang sedang dipelajarinya saja.

Berdasarkan pernyataan tersebut, kemampuan koneksi matematis sangat penting dimiliki oleh siswa. Namun, siswa yang menguasai konsep matematika tidak dengan sendirinya pintar dalam aktifitas terkait- mengkoneksikan matematika. Dalam sebuah penelitian ditemukan bahwa siswa sering mampu mendaftar konsep-konsep matematika yang terkait dengan masalah riil, tetapi hanya sedikit siswa yang mampu menjelaskan mengapa konsep tersebut digunakan. Dengan demikian kemampuan koneksi perlu dilatihkan kepada siswa, apabila siswa mampu mengkaitkan ide-ide matematika maka pemahaman matematikanya maka akan semakin dalam dan bertahan lama karena mereka mampu melihat keterkaitan antar topik dalam matematika, dengan konteks selain matematika, dan dengan pengalaman hidup sehari-hari (NCTM, 2000:64).

Penelitian yang dilakukan Pujianti (dalam Cancan, 2014 : 5) terhadap siswa Sekolah Menengah Pertama menunjukan bahwa kemampuan koneksi matematis siswa masih rendah. Hal ini di sebabkan oleh pembelajaran matematika di kelas yang masih cenderung menggunakan paradigma lama dengan menyajikan pengetahuan matematika tanpa mengaitkan materi yang diberikan dengan kehidupan keseharian siswa.

"Dalam pembelajaran di kelas, koneksi matematik antar konsep-konsep dalam matematik sebaiknya didiskusikan oleh siswa, pengkoneksian antar ide matematik yang diajarkan secara eksplisit oleh guru tidak membuat siswa memahaminya secara bermakna". Hiebert dan Carpenter, (dalam Sugiman, 2008). Pembelajaran yang sesuai adalah tidak dengan calk and talk saja namun siswa harus aktif melakukan koneksi sendiri. Dalam hal ini siswa tidak boleh dipandang sebagai passive 
receivers of ready-made mathematics, namun sebaliknya siswa dianggap sebagai individu aktif yang mampu mengembangkan potensi matematikanya sendiri.

Model pembelajaran yang dibutuhkan adalah yang mampu menghasilkan kemampuan untuk belajar. Menurut Zamroni dan Semiawan (dalam Yusrina, dkk., 2014) bukan saja diperolehnya sejumlah pengetahuan, keterampilan, dan sikap, tetapi yang lebih penting adalah bagaimana pengetahuan, keterampilan, dan sikap itu diperoleh siswa. Berkenaan dengan model pembelajaran yang dibutuhkan diatas, model pembelajaran berbasis pendekatan keterampilan proses diharapkan dapat menjadi alternatif.

"Pendekatan keterampilan proses pada hakikatnya adalah suatu pengelolaan kegiatan belajarmengajar yang berfokus pada pelibatan siswa secara aktif dan kreatif dalam proses pemerolehan hasil belajar". Semiawan (dalam Yusrina, 2014). Pendekatan keterampilan proses ini dipandang sebagai pendekatan yang oleh banyak pakar paling sesuai dengan pelaksanaan pembelajaran di sekolah dalam rangka menghadapi pertumbuhan dan perkembangan ilmu pengetahuan dan teknologi yang semakin cepat.

Penulis menduga bahwa dengan pendekatan keterampilan proses dapat meningkatkan kemampuan koneksi matematis siswa, karena model pembelajaran ini siswa dituntut aktif dan kreatif sehingga dapat mengetahui hubungan berbagai konsep dalam matematika dan mengaplikasikan matematika dalam kehidupan sehari-hari.

Dari uraian latar belakang masalah yang telah dikemukakan, dapat dirumuskan permasalahan yang akan diteliti sebagai berikut:

1. Bagaimana persepsi siswa terhadap pembelajaran Pendekatan Keterampilan Proses?

2. Bagaimana kemampuan koneksi matematis siswa setelah diberikan Pendekatan Keterampilan Proses?

3. Bagaimana pengaruh persepsi siswa tentang pembelajaran Pendekatan Keterampilan Proses terhadap kemampuan koneksi matematis siswa?

Persepsi berasal dari bahasa inggris "perception", yang diambil dari bahasa Latin "perceptio", yang berarti menerima atau mengambil. Dalam kamus Inggris-Indonesia, kata perception diartikan dengan penglihatan atau tanggapan. Tanpa ada persepsi yang benar kehadiran peserta didik disekolah, tidak akan mendapatkan kemanfaatan yang berarti dari informasi atau materi pelajaran yang disampaikan guru (Desmita, 2010:116).

Depdikbud (dalam Dimyati dan Mudjiono, 2002: 138) menyatakan bahwa "Pendekatan Keterampilan Proses dapat diartikan sebagai pendekatan pembelajaran yang dapat mengembangkan keterampilan intelektual, sosial, dan fisik yang bersumber dari kemampuan- kemampuan dasar yang pada prinsipnya telah ada pada diri siswa".

Dimiyati dan Mudjiono (2002: 138) mengatakan bahwa pendekatan keterampilan proses dimaksudkan untuk mengembangkan kemampuan yang dimiliki oleh siswa adalah :

1) Pendekatan keterampilan proses memberikan kepada pengertian yang tepat tentang hakekat ilmu pengetahuan siswa dapat mengalami rangsangan ilmu pengetahuan dan dapat lebih baik mengerti fakta dan konsep ilmu pengetahuan.

2) Mengajar dengan keterampilan proses berarti memberi kesempatan kepada siswa bekerja dengan ilmu pengetahuan tidak sekedar menceritakan atau mendengarkan cerita tentang ilmu pengetahuan.

3) Menggunakan keterampilan proses untuk mengajar ilmu pengetahuan membuat siswa belajar proses dan produk ilmu pengetahuan sekaligus.

Koneksi matematis merupakan dua kata yang berasal dari Mathematical Connection yang dipopulerkan oleh NCTM dan dijadikan sebagai standar kurikulum pembelajaran matematika sekolah dasar dan menengah (Sumarmo, 2006). Menurut National Council of Teacher of Mathematics (NCTM), koneksi matematika merupakan bagian penting yang harus mendapatkan penekanan di setiap jenjang pendidikan. Koneksi matematika adalah keterkaitan antara topik matematika, keterkaitan antara matematika dengan disiplin ilmu yang lain dan keterkaitan matematika 
JURNAL GANTANG Pendidikan Matematika FKIP - UMRAH

Vol. 1 No. 2, Desember 2016, p-ISSN. 2503-0671, e-ISSN. 2548-5547

dengan dunia nyata atau dalam kehidupan sehari-hari.

Ulep (dalam Yulianti, 2004) mengemukakan ada beberapa indikator koneksi matematis, sebagai berikut :" 1) Menyelesaikan masalah dengan menggunakan grafik, hitungan numerik, aljabar, dan representasi verbal; 2) Menerapkan konsep dan prosedur yang telah diperoleh pada situasi baru; 3) Menyadari hubungan antar topik dalam matematika; 4) Memperluas ide-ide matematik".

Menurut Sumarmo (dalam Supriatin, 2009:19) mengemukakan beberapa indikator kemampuan koneksi matematika, yaitu:

a. Mencari hubungan berbagai representasi konsep dan prosedur.

b. Memahami hubungan antar topik dalam matematika

c. Menggunakan matematika dalam bidang studi lain atau dalam kehidupan sehari-hari.

d. Memahami representasi yang ekuivalen konsep atau prosedur yang sama.

e. Mencari koneksi antar topik matematika dan antar topik matematika dengan topik lain.

Berdasarkan indikator tersebut, dapat diketahui sejauh mana kemampuan koneksi matematis siswa dalam mempelajari matematika. Dengan demikian indikator yang digunakan dalam penelitian ini adalah: 1) Menyelesaikan masalah dengan menggunakan grafik, hitungan numerik, aljabar, dan representasi verbal; 2) Menerapkan konsep dan prosedur yang telah diperoleh pada situasi baru; 3) Memahami dan menerapkan koneksi antar topik dalam matematika; 4) Memahami dan menerapkan koneksi matematika dengan kehidupan nyata atau kehidupan seharihari; 5) menggunakan atau menerapkan matematika dalam disiplin ilmu lain.

\section{Metode Penelitian}

Jenis penelitian yang digunakan dalam penelitian ini adalah penelitian eksperimen. (Rahadi, 2008: 24) menyatakan bahwa "Penelitian eksperimen adalah penelitian yang mengkaji sebab akibat dari suatu peristiwa dan pengaruh dari suatu variabel terhadap variabel yang lain dikaji dalam situasi yang terkontrol".

Penelitian ini dilakukan untuk mengetahui pengaruh persepsi pembelajaran dengan Pendekatan Keterampilan Proses (PKP) terhadap kemampuan koneksi matematis siswa dalam pembelajaran matematika. Oleh karena itu, penulis terjun langsung dan menerapkan pembelajaran dengan menggunakan Pendekatan Keterampilan Proses (PKP) yang sesuai dengan rumusan masalah dan tujuan penelitian yaitu dengan menguji hipotesis yang telah ada.

Populasi dalam penelitian ini adalah seluruh siswa SMP Negeri 1 Wanaraja, tahun akademik 2014-2015. Sampel yang diambil adalah seluruh kelas VIII yang dipilih secara acak dan diperoleh kelas VIII A dengan jumlah siswa 35 orang sebagai kelompok eksperimen. Kelompok eksperimen adalah kelompok yang mendapatkan pendekatan keterampilan proses.

\section{Hasil dan Pembahasan}

Dari hasil penelitian diperoleh datadata dari kelas pendekatan keterampilan proses, yaitu berupa nilai hasil belajar matematika siswa dari hasil tes akhir (post-test) dan angket siswa. Kemudian data-data yang diperoleh tersebut dianalisis, sehingga diperoleh suatu kesimpulan berkenaan dengan hipotesis yang diajukan.

\section{Deskripsi Data Hasil Penelitian}

Dari data hasil penelitian dengan memberikan perlakuan pada kelas VIII-A sebagai kelompok eksperimen yang mendapatkan pendekatan Keterampilan Proses dengan jumlah siswa 35 siswa, diberikan tes akhir dan angket persepsi siswa, diperoleh hasil sebagai berikut:

Tabel 1. Data Hasil Penelitian

\begin{tabular}{|r|c|c|}
\hline Keterangan & Data Hasil Angket Persepsi Siswa & Data Hasil Tes Akhir \\
\hline Nilai Tertinggi & 96 & 26 \\
\hline Nilai Terendah & 63 & 14 \\
\hline
\end{tabular}




\begin{tabular}{|c|c|c|}
\hline Jumlah & 2713 & 724 \\
\hline
\end{tabular}

\section{Analisis Data Hasil Angket Penelitian}

Pada akhir pembelajaran setiap siswa diberikan angket, hal ini dimaksudkan untuk mengetahui respon siswa terhadap pembelajaran matematilka dengan menggunakan pendekatan keterampilan proses.

Angket yang diberikan terdiri dari 20 pernyataan yang dikelompokkan berdasarkan aspek yang ingin diteliti dimulai dari bagaimana persepsi siswa terhadap pembelajaran matematika dengan pendekatan keterampilan proses, dan bagaimana persepsi siswa terhadap pelajaran matematika.

Interpretasi Persepsi Siswa Secara Umum

Berdasarkan perhitungan, didapat nilai maksimal 3500, nilai minimal 700, rentang 2800, dan panjang kelas 560. Sehingga menghasilkan skala tanggapan sebagai berikut

Tabel 2. Skala Tanggapan Interpretasi Siswa secara Umum

\begin{tabular}{|l|l|}
\hline Skor & Interpretasi \\
\hline $700 \leq$ JST $\leq 1260$ & Sangat Jelek \\
\hline $1261<$ JST $\leq 1820$ & Jelek \\
\hline $1821<$ JST $\leq 2380$ & Cukup \\
\hline $2381<$ JST $\leq 2940$ & Baik \\
\hline $2941<$ JST $\leq 3500$ & Sangat Baik \\
\hline
\end{tabular}

Keterangan : JST $=$ Jumlah skor total

Dari hasil perhitungan, diperoleh bahwa skor total angket adalah sebesar 2713. Sehingga interpretasi siswa secara umum kelas eksperimen mengenai persepsi siswa terhadap pendekatan keterampilan proses dan pelajaran matematika adalah Baik. Seperti disajikan pada tabel berikut ini:

Tabel 3. Interpretasi Persepsi Siswa secara Umum

\begin{tabular}{|lr|l|l|}
\hline Sikap & Jumlah Skor Tota & Interpretasi Siswa \\
\hline Terhadap rembelajara & & \\
Matematika & denga & & \\
Pendekatan & Keterampila & 2713 & Baik \\
Proses & & \\
\cline { 1 - 1 } Terhadap pelajaran Matematik & & \\
\hline
\end{tabular}

\section{Interpretasi Persepsi Siswa Tiap Individu}

Berdasarkan perhitungan interpretasi skala persepsi pada masing-masing individu dikelas eksperimen terhadap pembelajaran matematika dengan menggunakan pendekatan keterampilan proses diperoleh data sebagai berikut:

Tabel 4. Data Interretasi Siswa Tiap Individu

\begin{tabular}{|l|l|l|l|l|}
\hline No & Skala Tanggapan & Interpretasi Persepsi Sisw & Frekuensi & Persentasi (\%) \\
\hline 1. & $20 \leq$ JST $\leq 36$ & Sangat Baik & 6 & 17,14 \\
\hline 2. & $37<$ JST $\leq 52$ & Baik & 27 & 77,14 \\
\hline 3. & $53<$ JST $\leq 68$ & Cukup & 2 & 5,72 \\
\hline 4. & $69<$ JST $\leq 84$ & Jelek & 0 & - \\
\hline
\end{tabular}


JURNAL GANTANG Pendidikan Matematika FKIP - UMRAH

Vol. 1 No. 2, Desember 2016, p-ISSN. 2503-0671, e-ISSN. 2548-5547

\begin{tabular}{|l|l|l|l|l|}
\hline 5. & $85<$ JST $\leq 100$ & Sangat Jelek & 0 & - \\
\hline Jumlah & 35 & 100 \\
\hline
\end{tabular}

Keterangan: JST $=$ Jumlah skor total

Berdasar tabel 4 persepsi siswa terhadap pembelajaran Pendekatan Keterampilan Proses, diperoleh 6 siswa yang berinterpretasi sangat baik dengan $17,14 \%$; 27 siswa berinterpretasi baik dengan $77,14 \%$; dan 2 siswa berinterpretasi Cukup dengan $5,72 \%$.

\section{Analisis Data Kemampuan Koneksi Matematis} Siswa
Berdasarkan hasil perhitungan yang telah dilakukan dari 35 siswa yang diberikan tes akhir kemampuan diperoleh rata - rata nilai kemampuan koneksi matematisnya adalah 74 , sehingga secara keseluruhan siswa kelas eksperimen tersebut berinterpretasi baik. Berikut ini disajikan data distribusi frekuensi untuk kemampuan koneksi matematis siswa sebagai berikut:

Tabel 5. Data Hasil Analisis Kemampuan Koneksi Matematis Siswa

\begin{tabular}{|l|l|l|l|l|}
\hline No & Kriteria & Interpretasi KKM & Frekuensi & Persentasi (\%) \\
\hline 1. & $80 \leq$ Nilai $\leq 100$ & Sangat Baik & 11 & $31.43 \%$ \\
\hline 2. & $70 \leq$ Nilai $<80$ & Baik & 13 & $37.14 \%$ \\
\hline 3. & $60 \leq$ Nilai $<70$ & Cukup & 6 & $17.14 \%$ \\
\hline 4. & $50 \leq$ Nilai $<60$ & Kurang & 5 & $14.29 \%$ \\
\hline 5. & $0 \leq$ Nilai $<50$ & Sangat Kurang & 0 & 0 \\
\hline Jumlah & 35 & 100 \\
\hline
\end{tabular}

\section{Analisis Data Korelasi}

Karena datanya dalam bentuk skala ordinal maka dilanjutkan dengan koefisien korelasi Rank Spearman. Dari hasil perhitungan diperoleh data yang disusun sebagai berikut:

Tabel 6. Data Hasil Analisis Korelasi Rank Spearman

\begin{tabular}{|l|l|l|l|l|l|}
\hline $\boldsymbol{\Sigma} \boldsymbol{x}^{2}$ & $\boldsymbol{\Sigma} \boldsymbol{y}^{2}$ & $\boldsymbol{\Sigma} \boldsymbol{d i}^{2}$ & Koefisien Korekasi $\left(\boldsymbol{r}_{s}\right)$ & Sifat Koefisien Korelasi & Kriteria \\
\hline 3547,5 & 3523,5 & 3713,5 & 0,4748 & Positif & Sedang \\
\hline
\end{tabular}

Berdasarkan tabel 4.18 terlihat bahwa besar koefisien korelasinya adalah 0,4748. Karena nilai koefisien korelasi $\left(\boldsymbol{r}_{s}>0\right)$ maka dikatakan berkorelasi positif. Dan kriteria penilaian korelasinya berada pada $(0.40-0.599)$, sehingga tingkat hubungannya sedang.

Selanjutnya koefisien korelasi yang dihasilkan tersebut, di uji dengan menggunakan uji t. Berdasarkan hasil uji t, diketahui:

$$
\begin{gathered}
t_{\text {hitung }}=\frac{r \sqrt{n-2}}{\sqrt{1-r^{2}}} \\
t_{\text {hitung }}=\frac{0,4748 \sqrt{35-2}}{\sqrt{1-0,4748^{2}}}=\frac{2,7275}{0,8801}=3,0991 \text { dan } \\
\mathrm{t}_{\text {tabel }}=\mathrm{t}_{\alpha}(\mathrm{dk}=\mathrm{n}-2)=\mathrm{t}_{0.05}(\mathrm{dk}=33)=2.0359 \\
\text { Sehingga didapat kriteria keberartian }
\end{gathered}
$$$$
\text { korelasi: nilai } \mathrm{t}_{\text {hitung }}=3,0991>\mathrm{t}_{\text {tabel }}=2.0359
$$

maka Ho ditolak (terdapat korelasi yang signifikan antar variabel), sehingga dapat disimpulkan bahwa terdapat pengaruh yang positif dan signifikan persepsi siswa tentang pembelajaran dengan Pendekatan Keterampilan Proses (PKP) terhadap kemampuan koneksi matematis siswa.

Dengan koefisien determinasi diperoleh besarnya pengaruh antara persepsi siswa tentang pembelajaran Pendekatan Keterampilan Proses (PKP) terhadap kemampuan koneksi matematis siswa sebesar 22,54\%.

\section{Pembahasan Hasil Penelitian}

Penelitian ini dilaksanakan di SMP Negeri 1 Wanaraja. Dari data hasil penelitian dengan memberikan perlakuan kepada kelas VIII- 
A sebagai kelompok yang mendapatkan pendekatan keterampilan proses dengan jumlah siswa 35 siswa dan pokok bahasan Lingkaran.

Pertemuan pertama pada kelompok yang mendapatkan pendekatan keterampilan proses dikelas VIII-A. Pada pertemuan ini guru menggunakan alat peraga dalam pembahasan unsur-unsur dan bagian-bagian lingkaran sehingga siswa antusias memperhatikan penjelasan guru. Akan tetapi siswa belum memberanikan diri untuk bertanya kepada guru atau siswa lain tentang materi yang tidak dimengerti. Walaupun begitu siswa aktif dalam mengerjakan latihan sehingga mulai interaktif dengan siswa lain.

Pertemuan kedua, pada pertemuan ini guru tidak menggunakan alat peraga dalam pembahasan keliling dan luas lingkaran namun siswa tetap antusias memperhatikan penjelasan guru. Guru memberikan bimbingan dan arahan sehingga siswa nampak lebih aktif, hal ini ditunjukkan dengan adanya kertelibatan siswa secara aktif dalam proses pembelajaran baik antara guru dengan siswa maupun siswa dengan siswa. Guru tetap memberikan kebebasan kepada siswa untuk memahami materi pelajaran sesuai dengan keinginannya, siswa sedikit memberanikan diri untuk bertanya kepada guru atau siswa lain tentang materi yang tidak dimengerti. Siswa antusias mengerjakan soal didepan kelas.

Pertemuan ketiga, pada pertemuan ini membahas mengenai hubungan sudut pusat dan sudut keliling yang menghadap busur yang sama. Siswa antusias memperhatikan penjelasan guru, guru memberikan bimbingan dan arahan sehingga siswa nampak lebih aktif, hal ini ditunjukkan dengan adanya kertelibatan siswa secara aktif dalam proses pembelajaran baik antara guru dengan siswa maupun siswa dengan siswa. Guru tetap memberikan kebebasan kepada siswa untuk memahami materi pelajaran sesuai dengan keinginannya sehingga siswa antusias dalam mengerjakan soal.

Pertemuan keempat, pada pertemuan ini membahas mengenai menentukan panjang busur, luas juring, dan luas tembereng. siswa antusias memperhatikan penjelasan guru dan bertanya kepada guru atau siswa lain tentang materi yang tidak dimengerti. Siswa mengerjakan buku LKS siswa dan aktif berdiskusi dengan temannya. Guru tetap memberikan bimbingan dan arahan kepada siswa, sehingga siswa antusias dalam mengerjakan.

Pertemuan kelima, pada pertemuan ini membahas materi mengenai menggunakan hubungan sudut pusat, panjang busur, luas juring dalam pemecahan masalah. Siswa antusias memperhatikan penjelasan guru dan bertanya kepada guru atau siswa lain tentang materi yang tidak dimengerti. Guru memberikan bimbingan dan arahan sehingga siswa nampak lebih aktif, hal ini ditunjukkan dengan adanya kertelibatan siswa secara aktif dalam proses pembelajaran baik antara guru dengan siswa maupun siswa dengan siswa. Guru tetap memberikan kebebasan kepada siswa untuk memahami materi pelajaran sesuai dengan keinginannya sehingga siswa antusias dalam mengerjakan soal dan berani mengerjakan di depan kelas.

Setelah proses pembelajaran selesai, diberikan tes kemampuan akhir (post-test) dan angket persepsi siswa. Berdasarkan hasil analisis yang telah dilakukan menunjukan bahwa terdapat pengaruh yang positif dan signifikan persepsi siswa tentang pembelajaran pendekatan keterampilan proses terhadap kemampuan koneksi matematis siswa.

Ada beberapa faktor yang ditemukan penulis yang menghambat berlangsungnya pelaksanaan pembelajaran dengan pendekatan keterampilan proses, diantaranya:

1. Siswa belum terbiasa dan paham dengan pembelajaran pendekatan keterampilan proses, sehingga pada saat pertama kali diterapkan siswa kurang aktif dalam proses pembelajaran. Untuk mengatasi hal tersebut guru memberikan pengertian, bimbingan, dan arahan mengenai pembelajaran yang sedang berlangsung.

2. Siswa belum terbiasa aktif untuk mengga li sendiri materi yang akan dipelajari, 
JURNAL GANTANG Pendidikan Matematika FKIP - UMRAH

Vol. 1 No. 2, Desember 2016, p-ISSN. 2503-0671, e-ISSN. 2548-5547

sehingga guru harus lebih memberikan bimbingan dan motivasi kepada siswa

3. Siswa kurang memahami konsep-konsep dalam menyelesaikan soal-soal latihan yang diberikan, terutama soal-soal yang berkaitan dengan kehidupan sehari-hari. Untuk mengatasinyaguru harus membiasakan siswa untuk megerjakan soal - soal dalam berbagai konsep serta memberikan pengertian, bimbingan, dan arahan kepada siswa bagaimana cara menyelesaikan soal-soal dengan pertanyaan-pertanyaan terbimbing untuk mendapatkan jawaban yang sesuai..

4. Beberapa siswa masih ada yang tidak memperhatikan saat proses pembelajaran sedang berlangsung. Untuk mengatasi hal tersebut guru harus lebih aktif berkeliling dan menghampiri kelompok siswa yang belum mengerti dan membimbingnya.

5. Sebagian besar siswa masih susah apabila disuruh ke depan kelas untuk mengerjakan soal dan menjelaskan. Sehingga untuk mengatasi hal tersebut guru harus memberikan motivasi kepada siswa untuk berani ke depan.

\section{Kesimpulan}

Berdasarkan hasil penelitian dan pembahasan secara keseluruhan, maka dapat ditarik simpulan sebagai berikut:

1. Persepsi siswa terhadap pembelajaran Pendekatan Keterampilan Proses (PKP) adalah baik.

2. Kemampuan matematis siswa setelah diberikan Pendekatan Keterampilan Proses (PKP) rata - rata berinterpretasi baik.

3. Terdapat pengaruh yang positif persepsi siswa tentang pembelajaran Pendekatan Keterampilan Proses (PKP) terhadap kemampuan koneksi matematis siswa.

Berdasarkan hasil penelitian dilapangan yang telah dilaksanakan sebelumnya, maka peneliti memiliki meyakini bahwa Pendekatan Keterampilan Proses dapat menjadi salah satu alternatif pendekatan pembelajaran inovatif yang dapat dilaksanakan oleh guru di kelasnya.

\section{Referensi}

Cancan. (2014). Perbandingan Kemampuan Koneksi Matematis antara Siswa yang Mendapat Model Pembelajaran Brain Based Learning dengan Siswa yang Mendapat Model Pembelajaran Konvesional. Skripsi pada Jurusan Pendidikan Matematika STKIP Garut: Tidak diterbitkan.

Desmita. 2010. Psikologi Perkembangan Peserta Didik. Bandung: PT Remaja Rosdakarya.

Dimyati dan Mudjiono. (2002). Belajar dan Pembelajaran. Jakarta: PT Rineka Cipta.

NCTM. (2003). NCTM Program

Standards.Programs For Initial

Preparation Of Mathematics Teachers.

Standards For Secondary Mathematics

Teachers.Sumber:

http://www.nctm.org/uploadedFiles/Mat

h_Standards/.

Rahadi, M. (2008). Metodologi Pendidikan. Modul STKIP. Garut: Tidak diterbitkan.

Sugiman. (2008). Koneksi Matematik dalam Pembelajaran Matematika di Sekolah Menengah Pertama. sumber: http://Jurnal.uny.ac.id/index.php/Pythag oras/article/view/687.

Sumarmo, U. (2006). Pembelajaran Keterampilan Membaca Matematika pada Siswa Sekolah Menengah. Sumber: http;//math.sps.upi.edu/epcontent/uploads/2010/02/MKLHKETBACA-MAT-NOV-06-new.pdf.

Supriatin, A. (2009). Penerapan Model Pembelajaran Tematik dalam Upaya Meningkatkan Kemampuan Koneksi Matematis dan Sikap Siswa SD. Tesis Pascasarjana UPI Bandung. Tidak diterbitkan.

Undang-Undang Sistem Pendidikan Nasional No. 20 Ayat 1 No $1 . \quad$ Sumber: http://www.dpr.go.id//uu/uu1989/UU_198 9 2.pdf

Yulianti, K. (2004). Penerapan model siklus belajar (Learning Cicle) pada 
pembelajaran barisan dan deret dalam upaya meningkatkan koneksi matematik siswa. Skripsi FPMIPA UPI. Bandung: Tidak diterbitkan.

Yusrina, dkk. (2014). Makalah Pendekatan dan penerapan keterampilan proses dalam pembelajaran matematika. Sumber:

http://Yusrina Fitriani

Ns.flock.com/2014/01/28/ Makalah

Pendekatan dan penerapan keterampilan proses dalam pembelajaran $\underline{\text { matematika.html. }}$ 
JURNAL GANTANG Pendidikan Matematika FKIP - UMRAH

Vol. 1 No. 2, Desember 2016, p-ISSN. 2503-0671, e-ISSN. 2548-5547 